\title{
Determinan Pengungkapan Aset Biologis (Studi Empiris pada Perusahaan Agriculture yang Terdaftar di Bursa Efek Indonesia
}

\author{
Viona Azzahra ${ }^{*}$, Elvira Luthan ${ }^{2}$, Amy Fontanella $^{3}$ \\ ${ }^{1}$ Student of Magister Degree of Accounting, Andalas University \\ ${ }^{2,3}$ Lecture of Accounting Department, Andalas University \\ *Correspondence email: vionaazzahra2623@gmail.com
}

\begin{abstract}
Disclosure of biological assets in agricultural companies has been ratified in 2018, which is about PSAK 69. This standard requires agricultural sector companies to provide disclosures about their biological assets. Several studies have been carried out by previous studies. However, studies in Indonesia are still limited. Therefore, there is a desire to investigate this phenomenon. The purpose of this study is to examine the influence of what factors influence the disclosure of biological assets. The population in this study are all agricultural companies listed on the Indonesia Stock Exchange for 2015-2018. The final sample in this study were 50 companies obtained using the purposive sampling method. Data were analyzed using multiple regression analysis. The results of this study indicate that the intensity of biological assets, Public Ownership, Audit Committee Meetings have a positive influence on the disclosure of biological assets.
\end{abstract}

Keywords : intensity of biological assets, public ownership, audit committee meetings, disclosure of biological assets.

\section{PENDAHULUAN}

Perusahaan yang bergerak di sektor agrikultur mempunyai peranan yang sangat penting terhadap pertumbuhan dan pembangunan ekonomi Indonesia.Beberapa peran yang dijalankan oleh perusahaan agrikultur adalah (i) sebagai sumber pendapatan (Hayati, 2017; Syafa'at, 2005; Todaro, 2011), (ii) sebagai penyedia lapangan pekerjaan (Hayati, 2017; Todaro, 2011), (iii) sebagai penghasil pangan untuk memenuhi kebutuhan dasar penduduk Indonesia (Syafa'at, 2005; Todaro, 2011). Perusahaan yang bergerak di sektor agrikultur juga merupakan penyumbang devisa negara karena sektor agrikultur menghasilkan produk-produk agrikultur yang berorientasi pada pasar ekspor (Syafa'at, 2005) dan menyediakan bahan baku (Todaro, 2011). Perusahaan yang bergerak di sektor agrikultur memiliki keunikan dibandingkan dengan perusahaan yang bergerak di sektor lainnya yaitu adanya aktivitas agrikultur.Menurut PSAK69, perusahaan di bidang agrikultur mencakup berbagai aktivitas seperti peternakan, kehutanan, tanaman semusim (annual) atau tahunan (perennial), budidaya kebun dan perkebunan, budidaya bunga, dan budidaya perikanan (termasukan perternakan ikan) memiliki karakteristik tertentu yang membedakannya dengan sektor lain. Hal ini ditunjukan oleh adanya manajemen transformasi biologis dan panen aset biologis. Menurut Sa'diyah et al (2019) Keunikan aset yang ada pada perusahaan agrikultur inilah yang disebut aset biologis.

Aset biologis menurut PSAK 69 adalah aset hewan atau tanaman hidup. aset biologis mengalami transformasi biologis dan panen aset biologis. Manajemen transformasi biologis meliputi proses pertumbuhan, degenerasi, produksi dan prokreasi yang menyebabkan perubahan kualitatif dan kuantitatif (PSAK 69). PSAK 69 mewajibkan perusahaan sektor agrikultur untuk memberikan pengungkapan tentang aset biologisnya. Menurut Owusu-Ansah (1998) pengungkapan adalah komunikasi informasi ekonomi yang dilakukan oleh perusahaan baik itu informasi keuangan maupun non keuangan, informasi kuantitatif maupun informasi lain yang mencerminkan posisi dan kinerja perusahaan. Oleh karena itu, menurut Healy \& Palepu (2001) harus ada regulasi yang memaksa perusahaan untuk menyampaikan informasi sesuai aktivitas yang dilakukan dengan tujuan untuk memperkecil kesenjangan informasi antara manajemen daninvestor. Selahudin et al (2018) Pentingnya pengungkapan aset biologis dalam laporan keuangan adalah untuk mempengaruhi pengambilan keputusan investor. Dengan demikian, informasi akuntansi harus lebih andal, akurat, dan relevan dengan aset biologis. Dengan meningkatkan informasi terkini, ini dapat mengarah pada tingkat transparansi yang tinggi yang meningkatkan kemandirian investor di pasar modal.

Penelitian ini menekankan pada pengungkapan aset biologisnya dalam laporan tahunan, mengenai tingkat transparansi perusahaan dalam menyajikan informasi. Selain itu, diperlukan pengungkapan informasi keuangan dan non-keuangan, itu akan meningkatkan pemahaman dan komparatif oleh pemangku kepentingan untuk membuat pengambilan keputusan yang lebih baik. Setiap perusahaan di Indonesia diharuskan untuk mengungkapkan informasi aset biologis yang dihasilkannya sebagai relevan dan dapat diandalkan dalam laporan keuangan. Tingkat transparansi akan meningkat dengan mengungkapkan lebih banyak informasi dalam laporan keuangan (Alim Al Ayub Ahmed, 2012). Namun, masih ada beberapa perusahaan yang tidak mengungkapkan informasi sesuai dengan praktik akuntansi yang dibutuhkan oleh pengguna (Tang, Gao dan Fu, 2013). Hal ini membuat para pengguna mengalami kesulitan untuk melakukan pengambilan keputusan dalam penilaian mereka. Berdasarkan penjelasan diatas penulis tertarik untuk 
meneliti apakah setelah di tetapkannya standar wajib PSAK 69 mengatur tentang perlakuan akuntansi dan pengungkapan terkait dengan aktivitas agrikultur, apakah perusahaan agrikultur di Indonesia memiliki tingkat kepatuhan yang tinggi terhadap pengungkapan aset biologis yang dimilikinya.

Penelitian tentang faktor-faktor yang mempengaruhi pengungkapan aset biologis belum banyak diteliti di Indonesia. Peraturan pengungkapan saja tidak dapat menjamin tingkat pengungkapan yang lebih tinggi sehingga diperlukan sistem institusional yaitu corporate governance untuk memonitor manajer dan mengelola perusahaan untuk menjamin bahwa perusahaan mengungkapkan informasi yang memadai. Beberapa faktor yang telah diteliti salah satunya adalah Biological Aset Intensity. Sa'diyahet al (2019) menjelaskan bahwa Biological asset intensity (intensitas aset biologis) adalah seberapa besar perusahaan berinvestasi pada aset biologis. Penelitian Goncalves \& patricia (2014); Yurniwati et al (2017); Selahudin et al (2018); Duwuet al (2018) menemukan bukti bahwa intensitas aset biologis mempunyai pengaruh positif dan signifikan terhadap pengungkapan aset biologis. Kepemilikan publik juga merupakan faktor yang mempengaruhi pengungkapan. Perusahaan yang sahamnya banyak dimiliki oleh publik mengharuskan perusahaan tersebut untuk melakukan pengungkapan informasi di dalam laporan keuangan mereka. Kondisi ini didasarkan pada pandangan bahwa pemegang saham menuntut informasi yang lebih lengkap tentang perusahaan untuk mengawasi aktifitas manajemen sehingga kepentingannya dalam perusahaan dapat terpenuhi (Nugraheni, 2009). Penelitian yang dilakukan oleh Nur (2012); Sriayu \& Nimba (2013) menemukan bukti bahwa kepemilikan saham publik berpengaruh signifikan terhadap pengungkapan.Tetapi berbeda dengan temuan penelitian yang dilakukan oleh Siregar (2017) bahwa kepemilikan publik tidak berpengaruh terhadappengungkapan.

Faktor lain yang mempengaruhi rapat komite audit (Ettredge et al, 2010). Komite audit memiliki peran dalam mengawasi pihak manajemen (agen) agar tidak melakukan tindakan yang dapat menguntungkan dirinya sendiri sehingga dapat merugikan pemilik perusahaan (Suhardjanto, 2012). Penelitian Ettredge et al (2010); Allegrini\& Giulio (2013) menemukan bukti bahwa semakin banyak rapat yang dilakukan oleh komite audit maka semakin mendorong kepatuhan pengungkapan wajib sedangkan penelitian yang dilakukan Suhardjanto (2012) rapat komite audit tidak berpengaruh terhadap pengungkapan. Temuan beberapa peneliti di atas menunjukkan adanya ketidakkonsistenan hasil penelitian tentang faktor-faktor yang mempengaruhi pengungkapan aset biologis sehingga peneliti menjadi tertarik untuk meneliti kembali tentang faktor- faktor yang mempengaruhi pengungkapan aset biologis. Selain itu, penelitian ini meneliti pengaruh rapat komite audit dan kepemilikan publik yang belum pernah diteliti sebelumnya. Tujuan penelitian ini adalah menguji pengaruh intensitas aset biologis dan Corporate Governance terhadap pengungkapan aset biologis serta menguji perbedaan pengungkapan sebelum dan setelah disahkannya Standar tentang PSAK 69.

\section{Literature Review}

Agency Theory

Jensen \& Meckling (1976) menjelaskan bahwa teori agensi adalah sebuah teori yang menjelaskan hubungan yang terjadi antara principal (pemilik saham atau investor) dengan agent (manajer perusahaan). Dalam hubungan ini, manajer perusahaan mempunyai peran menjalankan operasionalisasi perusahaan. Teori agensi timbul karena principal hanya melakukan investasi dalam perusahaan dan tidak secara langsung mengelola perusahaan tersebut namun mendelegasikan tugas pengelolaan tersebut kepada agent. Agent dalam menjalankan perusahaan mempuyai informasi yang lebih banyak dibandingkan dengan principal.Kondisi ini mengakibakan terjadinya ketidakseimbangan informasi atau asimetri informasi. Healy \& Palepu (2001) menjelaskan bahwa salah satu cara untuk mengatasi permasalahan tersebut adalah adanya pengungkapan informasi oleh agent sehingga principal mampu melakukan evaluasi tentang apakah investasi mereka telah dikelola dengan baik atau tidak oleh agent. Pengungkapan merupakan salah satu mekanisme yang tepat untuk memonitoring kinerja agent serta dapat meningkatkan kredibilitas perusahaan di mata pamegang saham.

\section{SignalingTheory}

Pengungkapan informasi perusahaan secara memadai kepada pemilik makahal tersebut merupakan sinyal baik (good news) bagi perusahaan. Salah satusinyal tersebut dapat berupa informasi keuangan yang dapat dipercaya dandapat mengurangi ketidakpastian mengenai masa depan perusahaan (Hargyantoro, 2010). Pihak pemilik cenderung memilih melakukanpengungkapan dengan harapan pihak investor dapat menginterpretasikannyasebagai sinyal positif mengenai kinerja perusahaan dan mampu mengurangiasimetri informasi. Pengungkapan merupakan suatu sinyal, karena denganpengungkapan dapat meningkatkan nilai perusahaan (Agustina, 2008), memberi informasi mengenai apa yang telah dilakukan oleh manajemenuntuk merealisasikan keinginan pemilik, dan memberi informasi-informasilainnya yang dapat membuat keyakinan bahwa perusahaan tersebut lebihbaik dari perusahaan lainnya (Hargyantoro, 2010). 
Viona Azzahra et al, Determinan Pengungkapan Aset Biologis (Studi Empiris pada Perusahaan Agriculture yang Terdaftar di Bursa Efek Indonesia

\section{Aset Biologis}

Aset biologis adalah hewan atau tanaman hidup yang mengalami transformasi biologis (proses pertumbuhan, degenerasi, produksi dan prokreasi) dari waktu ke waktu (PSAK 69, 2015; Obodoekwe, 2018). Transformasi biologis mengakibatkan terjadinya perubahan kualitatif atau kuantitatif aset biologis. PSAK 69 (2015) menjelaskan bahwa transformasi biologis menghasilkan output sebagai berikut :

Perubahan aset melalui: (a) Pertumbuhan (peningkatan kuantitas atau perbaikan kualitas hewan atau tanaman); (b) Degenerasi (penurunan kuantitas atau penurunan kualitas hewan atau tanaman); (c) Prokreasi (penciptaan hewan atau tanaman hidup tambahan); dan (d) Produksi produk pertanian seperti getah karet, daun teh, wol, dansusu.

\section{Intensitas aset biologis}

Secara umum, intensitas didefinisikan sebagai tingkat upaya perusahaan dalam memberikan informasi kepada pengguna laporan tahunan (Selahudin et al, 2018). Biological Asset Intensity (Intensitas Aset Biologis) menunjukkan besarnya nilai investasi pada aset biologis perusahaan. Selain menunjukkan besarnya investasi, juga memberikan gambaran jika nilai aset biologis tinggi maka perusahaan mengungkapan intensitas aset biologis dalam catatan atas laporan keuangan (Yurniwati et al, 2018).

\section{Corporate Governance}

Forum for Corporate Governace in Indonesia(2000: 1) mendefinisikan corporate governance sebagai: Seperangkat peraturan yang mengatur hubungan antara pemegang saham, pengurus pengelola) perusahaan, pihak kreditur, pemerintah, karyawan serta para pemegang kepentingan intern dan ekstern lainnya yang berkaitan dengan hakhak dan kewajiban mereka, atau dengan kata lain suatu sistem yang (mengatur dan mengendalikan perusahaan)". Implementasi GCG (good corporate governance) sudah banyak diterapkan di berbagai perusahaan di Indonesia.Penerapan GCG di Indonesia berawal sejak ditandatanganinya Letter Of Intent (LOI) yang bekerjasama dengan IMF yang di dalamnya terdapat pencantuman jadwal perbaikan pengelolaan perusahaan-perusahaan di Indonesia. Selain itu, Komite Nasional Kebijakan Governance (KNKG) (2006) menjelaskan perusahaan-perusahaan di Indonesia mempunyai tanggung jawab untuk menerapkan standar GCG yang telah diterapkan di tingkat Internasional. Menurut KNKG (2006) terdapat lima asas dalam GCG yaitu: transparansi, akuntabilitas, responsibilitas, independensi, dan kewajaran dan kesetaraan.

Tujuan diterapkannya good corporate governance adalah untuk menciptakan nilai tambah bagi semua pihak yang berkepentingan (stakeholders) secara berkesinambungan dalam jangka panjang. Corporate governance adalah seperangkat peraturan yang mengatur hubungan antara pemegang saham, pengurus (pengelola) perusahaan, pihak kreditur, pemerintah, karyawan, serta para pemegang kepentingan internal dan eksternal lainnya yang berkaitan dengan hak-hak dan kewajiban mereka atau dengan kata lain suatu sistem yang mengendalikan perusahaan. Indonesia menganut sistemdua tingkat atau Two Tiers System, artinya perusahaan mempunyai dua badan terpisah, yaitu dewan pengawas (dewan komisaris) dan dewan manajemen (dewan direksi). Dari penjelasan di atas dapat disimpulkan bahwa struktur corporate governance merupakan suatu susunan organ di dalam perusahaan yang menjalankan fungsi tata kelola sebagai pihak pengawas dan pihak yang menjalankan perusahaan (Prawinandi et al., 2012). Berdasarkan penjelasan diatas peneliti menggunakan kualitas komite audit dan kepemilikan publik dalam penelitian ini.

\section{Rapat Komite Audit}

Komite audit memiliki peran dalam mengawasi pihak manajemen (agen) agar tidak melakukan tindakan yang dapat menguntungkan dirinya sendiri sehingga dapat merugikan pemilik perusahaan (Suhardjanto, 2012). Komite audit juga dipandang sebagai alat untuk menghindari kecurangan dalam pelaporan keuangan dan memonitoring kinerja manajemen. Semakin besar komite audit didalam perusahaan akan meningkatkan pengawasan terhadap auditor dan kinerja manajemen sehingga pelaporan keuangan semakin berkualitas serta akan mempengaruhi tingkat kepatuhan mandatory disclosure perusahaan sesuai dengan konvergensi IFRS (Gunawan et al, 2016).

\section{Kepemilikan Publik}

Perusahaan yang telah go public dan telah terdaftar di Bursa Efek Indonesia (BEI) adalah perusahaan yang memiliki proporsi kepemilikan oleh publik yang artinya semua keadaan dan aktivitas yang dilakukan perusahaan wajib dilaporkan dan diketahui oleh publik karena publik sebagai salah satu pemegang saham (Fima, 2014). Kepemilikan publik diartikan sebagai kepemilikan saham yang dikuasai oleh masyarakat.Semakin besar kepemilikan saham yang dikuasai oleh publik, maka tuntutan pengungkapan informasi juga semakin tinggi (Choi, 2010). Publik sendiri adalah individu atau institusi yang memiliki kepemilikan saham dibawah 5\% yang berada di luar manajemen dan tidak memiliki hubungan istimewa dengan perusahaan (Eka, 2011). Pengertian publik disini adalah pihak lain diluar manajemen dan 
tidak memiliki hubungan istimewa dengan perusahaan. Semakin banyak saham dijual ke publik maka semakin banyak pula saham perusahaan yang beredar dimasyarakat. Semakin besar komposisi saham perusahaan yang dimiliki publik, maka akan semakin menuntut perusahaan untuk meluaskan pengungkapan informasi secara sukarela. Kondisi ini didasarkan pada alasan bahwa pemegang saham menuntut informasi yang lebih lengkap tentang perusahaan untuk mengawasi aktifitas manajemen sehingga kepentingannya dalam perusahaan dapat terpenuhi (Nugraheni, 2009)

\section{Hipotesis}

Hipotesis penelitian ini adalah:

$\mathrm{H}_{1}$ : Intensitas aset biologis berpengaruh positif terhadap pengungkapan aset biologis

$\mathrm{H}_{2}$ : Kepemilikan publik berpengaruh positif terhadap pengungkapan aset biologis

\section{METODE}

Penelitian ini merupakan penelitian kuantitatif. Menurut Sugiyono (2016) penelitian kuantitatif jenis penelitian yang berlandasankan pada filsafat positivisme, yang digunakan untuk meneliti pada populasi atau sampel tertentu, dengan tujuan untuk menguji hipotesis yang telah ditetapkan. Populasi dalam penelitian ini adalah seluruh perusahaan agriculture yang terdaftar di Bursa Efek Indonesia. Peneliti memilih sektor agriculture karena sektor ini masih menjadi salah satu kunci kekuatan ekonomi nasional dengan menyumbang Produk Domestik Bruto Indonesia sebesar 12,65\% pada TW I tahun 2019 dan 13,57\% pada TW II tahun 2019 (BPS, 2019). Selain itu aset biologis hanya terdapat pada perusahaan sektor agriculture saja. Penentuan sampel dipilih dari populasi perusahaan berdasarkan purposive sampling. Periode penelitian adalah tahun 2015-2018. Pemilihan sampel menggunakan metode purposive sampling dengan kriteria sebagai berikut:

a. Perusahaan Agrikultur yang terdaftar di BEI pada tahun2015-2018

b. Perusahaan menerbitkan laporan keuangan yang telah di audit selama tahun 2015-2018

c. Perusahaan mempublikasikan laporan keuangan utuk periode 31 Desember 2015 - 2018 yang dinyatakan dalam rupiah $(\mathrm{Rp})$

Jenis data yang dipergunakan dalam penelitian ini adalah data sekunder berupa laporan tahunan perusahaan periode 2015 - 2018. Data sekunder dalam penelitian ini antara lainannual report perusahaan agrikultur yang terdaftar di Bursa Efek Indonesia (BEI) yaitu www.idx.co.id serta masing- masing perusahaan sampel. Variabel dependen dalam penelitian ini adalah pengungkapan aset biologis yaitu merupakan penyampaian informasi secara formal di dalam laporan tahunan oleh perusahaan agrikultur terkait dengan aset biologis yang dikelolanya. Analisis data yang dilakukan dengan content analysis, yaitu menganalisis terhadap isi dari suatu dokumen untuk mengidentifikasi karakteristik atau informasi spesifik pada dokumen, sehingga menghasilkan deskripsi yang objektif dan sistematis. Content analysis dilakukan melalui laporan tahunan perusahaan dengan mengambil data yang diperlukan kemudian dianalisis. Tahap menganalisis perlakuan akuntansi atas aset biologis perusahaan, mengidentifikasi perlakuan akuntansi (pengungkapan) aset biologis pada perusahaan. Pengungkapan aset biologis diukur dengan menggunakan rumus Indeks Pengungkapan Wallace, yaitu :

Indeks Pengungkapan Wallace $=\frac{n}{K} \times 100 \%$

$\mathrm{n}=$ Luas pengungkapan aset biologis yang diperoleh dengan cara apabila setiap item diungkap dalam laporan tahunan maka diberi skor 1 (satu) dan apabila tidak diungkap dalam laporan tahunan, maka akan diberi skor 0 (nol).

$\mathrm{K}=$ Total skor yang diwajibkan menurut PSAK 69

\section{Uji Asumsi Klasik}

Uji Normalitas

Menurut Ghozali (2016), uji normalitas bertujuan untuk menguji apakah dalam model regresi, variabel pengganggu atau residual memiliki distribusi normal, seperti diketahui bahwa uji $t$ dan $\mathrm{f}$ mengasumsikan bahwa nilai residual mengikuti distribusi normal. Pengujian normalitas residual data penelitian ini menggunakan one-sample Kolmogorov- Smirnow test (K-S), yang jika tingkat signifikansi > 0,05 maka data terdistribusi secara normal.

\section{Uji Multikololinieritas}

Menurut Ghozali (2016), uji multikolinieritas bertujuan untuk menguji apakah model regresi ditemukan adanya kolerasi yang tinggi atau sempurna di antara variabel bebas atau tidak. Untuk mendeteksi ada tidaknya multikolinieritas dapat dilihat pada besaran Variance Inflation Factor (VIF) dan Tolerance.Pedoman suatu model regresi yang bebas multikolinieritas adalah mempunyai angka tolerance mendekati 1, batas VIF adalah 10, jika nilai VIF dibawah 10, maka tidak terjadi gejala multikolinieritas. 


\section{Uji Autokorelasi}

Menurut Ghozali (2016), uji autokorelasi bertujuan untuk melihat apakah dalam sebuah regresi linear ada korelasi antara kesalahan pengganggu pada periode $t$ dengan kesalahan pengganggu pada periode $\mathrm{t}-1$ (sebelumnya). Autokorelasi muncul ketika observasi yang berurutan sepanjang waktu berkaitan satu sama lainnya. Hal ini sering ditemukan pada data runtun waktu (times series).

\section{Uji Heterokedastisitas}

Uji Heteroskedastisitas bertujuan menguji apakah dalam model regresi terjadi ketidaksamaan variance dari residual satu pengamatan ke pengamatan yang lain. Jika variance dari residual satu pengamatan ke pengamatan lain tetap, maka disebut Homoskedastisitas dan jika berbeda disebut Heteroskedastisitas. Model regresi yang baik adalah yang Homoskedatisitas atau tidak terjadi Heteroskedatisitas (Ghozali, 2016). Salah satu cara untuk mendeteksi ada atau tidaknya heterokedastisitas adalah dengan menggunakan grafik Scatterplot antara nilai prediksi variabel terikat (dependen) yaitu ZPRED dengan residualnya SRESID.

\section{Analisis Regresi Berganda}

Analisis penelitian ini menggunakan regresi linear berganda karena variabel bebas lebih dari satu.Analisis regresi berganda digunakan untuk mengukur kekuatan hubungan antara dua variabel atau lebih, juga menunjukkan arah hubungan variabel dependen dan variabel independen dengan tujuan untuk mengestimasi atau memprediksi rata-rata populasi atau nilai rata-rata variabel dependen berdasarkan nilai variabel independen yangdiketahui (Ghozali, 2016). Analisis regresi berganda dalam penelitian ini digunakan untuk menguji Biological Asset Intensity $\left(\mathrm{X}_{1}\right)$, Kepemilikan Publik $\left(\mathrm{X}_{2}\right)$ dan Rapat Komite Audit $\left(\mathrm{X}_{3}\right)$ terhadap Tingkat Kepatuhan pengungkapan aset biologis (Y). Penelitian ini menggunakan persamaan regresi linear berganda.

\section{Uji Koefisien Determinasi}

Koefisien determinan $\left(\mathrm{R}^{2}\right)$ dimaksudkan untuk mengetahui tingkat ketepatan paling baik dalam analisis regresi, dimana hal yang ditunjukkan oleh besarnya koefisiensi determinasi $\left(\mathrm{R}^{2}\right)$ antara 0 (nol) dan 1 (satu). Koefisien determinasi $\left(\mathrm{R}^{2}\right)$ nol variabel independent sama sekali tidak berpengaruh terhadap variabel dependen. Apabila koefisien determinasi semakin mendekati satu, maka dapat dikatakan bahwa variabel independent berpengaruh terhadap varibel dependen. Selain itu koefisien determinasi dipergunakan untuk mengetahui presentase perubahan variabel terikat (Y) yang disebabkan oleh variabel bebas $(\mathrm{X})$.

\section{Uji Statistik t (t-test)}

Menurut Ghozali (2013), t test pad dasarnya nenunjukan seberapa jauh pengaruh satu variabel independen secara individual dalam menerangkan variabel dependen. Pengujian dilakukan dengan cara membandingkan t tabel dengan $t$ hitung, jika t hitung besar dati $t$ tabel maka Ha diterima begitu juga sebaliknya. Dan jika nilai sig besar dari 0,05 maka Ha diterima.

\section{HASIL}

Penelitian ini bertujuan untuk mendapatkan bukti secara empiris, apakah terdapat pengaruh intensitas aset biologis, pertumbuhan perusahaan, leverage, kepemilikan publik, rapat komite audit terhadap pengungkapan aset biologis pada perusahaan agrikultur di Bursa Efek Indonesia periode tahun 2015-2018 yang dipilih menggunakan metode purposive sampling. Berdasarkan kriteria yang telah ditetapkan pada bab III diperoleh jumlah sampel sebanyak 17 perusahaan agrikultur yang terdaftar di Bursa Efek Indonesia periode tahun 2015-2018. Jumlah sampel sebanyak 17 perusahaan dengan periode pengamatan selama 4 tahun. Berikut disajikan kriteria pemilihan sampel pada tabel 1 berikut ini:

Tabel 1.

Proses Pemilihan Sampel

\begin{tabular}{|c|c|c|}
\hline No & Kriteria Pemilihan Sampel & Jumlah \\
\hline 1 & Perusahaan agrikultur yang terdaftar di Bursa Efek Indonesia & 21 \\
\hline 2 & $\begin{array}{l}\text { Perusahaan agrikulturyang tidak menerbitkan laporan keuangan tahunan yang telah diaudit selama tahun } \\
\text { pengamatan periode } 2015-2018 \text {. }\end{array}$ & (3) \\
\hline \multirow[t]{2}{*}{3} & Perusahaan yang tidak menyatakan dalam rupiah (Rp) & (1) \\
\hline & Jumlah sampel yang digunakan dalam penelitian & 17 \\
\hline
\end{tabular}


Viona Azzahra et al, Determinan Pengungkapan Aset Biologis (Studi Empiris pada Perusahaan Agriculture yang Terdaftar di Bursa Efek Indonesia

\section{Pengungkapan Aset Biologis}

Pengungkapan aset biologis dihitung berdasarkan item pengungkapan PSAK 69. Total pengungkapan sebanyak 40 item. Selanjutnya untuk mengukur luas pengungkapan dengan membandingkan total skor yang dipeoleh dengan total skor yang diwajibkan oleh PSAK 69. Tabel hasil pengungkapan aet biologis ada pada lampiran. Untuk lebih jelasnya dapat dilihat pada gambar dibawah ini :

\section{Gambar 1}

Hasil skor pengungkapan aset biologis perusahaan

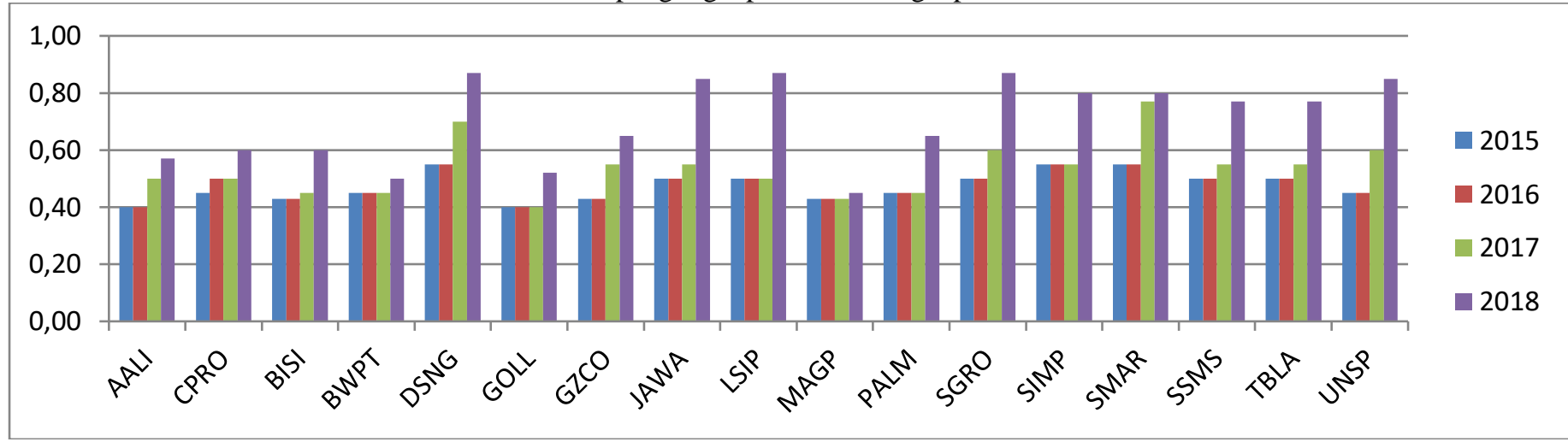

Sumber: data olahan

Gambar 1 diatas terlihat bahwa mayoritas perusahaan yang melakukan pengungkapan aset biologis dengan total skor yang berbeda setiap tahunnya. Ada beberapa perusahaan yang melakukan pengungkapan lebih terhadap aset biologis yang dikelolanya seperti PT Dharma Satya Nusantara, PT PP London Sumatra Indonesia, PT Sampoern Agro. Berdasarkan grafik diatas perusahaan dengan skor rendah adalah PT Astra Agro Lestari Tbk, PT Central Proteina Prima Tbk, PT Eagle High Plantations, PT Golden Plantation, PT Multi Agro Gemilang Plantation Tbk. Penyebab kecilnya skor pengungkapan aset biologis dikarenakan masih banyak perusahaan agrikultur yang belum mengungkapkan perlakuan terhadap aset biologisnya saat panen, saat penghentian dan juga tidak mengungkapakn terkait hibah pemerintah dalam laporan tahunan perusahaan. Perusahaan masih mengukur aset biologisnya berdasarkan harga perolehan dikurangi dengan akumulasi penyusutan. Pada umumnya perusahaan yang memiliki skor rendah Aset biologis terbagi atas aset tanaman semusim (ATS), Tanaman Belum Menghasilkan (TBM), Tanaman Menghasilkan (TM) dan persediaan hasil panen. Sedangkan yang diterapkan dalam PSAK 69 aset biologis diakui sebagai aset biologis belum dewasa, aset biologis dewasa dan persediaan. Perusahaan mengungkapan adanya penyusutan yang berdampak pada penurunan laba rugi pada tahun berjalan, serta mengungkapkan metode penyusutan yang digunakan, umur, manfaat ekonomi, dan tarif penyusutan yang digunakan. Sedangkan pada PSAK 69 tidak mengungkapkan adanya penyusutan aset biologis, maka pada laporan laba/rugi tidak ada beban depresiasi yang berakibat adanya kenaikan pada laporan laba/rugi, kecuali berlaku jika penyusutan diakui ketika nilai wajar tidak dapat ditentukan sehinga perusahaan menilai aset biologis dengan biaya perolehan, dan metode serta tarif penyusutannya sesuai dengan kebijakan perusahaan, hal inilah membuat nilai pengungkapan menjadi rendah.

\section{Analisis Statistik Deskriptif}

Statistik deskriptif merupakan proses transformasi data penelitian dalam bentuk tabulasi sehingga mudah dipahami dan diinterprestasikan (Suyonto, 2013). Analisis statistik deskriptif akan memberikan deskripsi mengenai nilai rata-rata (mean), standar deviasi, nilai maksimum, dan nilai minimum dari variabel dalam penelitian ini. Nilai minimum merupakan nilai terkecil dari suatu rangkaian pengamatan. Nilai maksimum merupakan nilai terbesar dalam suatu rangkaian pengamatan. Mean merupakan rata-rata yang dihitung dari penjumlahan nilai seluruh data dibagi dengan banyaknya data, dan standar deviasi merupakan akar dari jumlah kuadrat selisih nilai data dengan rata-rata dibagi dengan banyaknya data (Santoso, 2010). Berdasarkan olahan data SPSS yang meliputi Pengungkapan Aset Biologis (Y), Intensitas Aset Biologis $\left(\mathrm{X}_{1}\right)$, Kepemilikan Publik $\left(\mathrm{X}_{2}\right)$, Rapat Komite Audit $\left(\mathrm{X}_{3}\right)$, maka akan diketahui nilai maksimum, nilai minimum, nilai rata-rata (mean), dan standar deviasi dari setiap variabel. Berikut merupakan hasil statistik deskriptif masing-masing variabel pada tabel 2 dibawah ini: 
Viona Azzahra et al, Determinan Pengungkapan Aset Biologis (Studi Empiris pada Perusahaan Agriculture yang Terdaftar di Bursa Efek Indonesia

Tabel 2.

Statistik deskriptif

\begin{tabular}{|c|c|c|c|c|c|}
\hline & $\mathrm{N}$ & Minimum & Maximum & Mean & Std. Deviation \\
\hline Pengungkapan Aset Biologis & 50 & 0.40 & 0.87 & 0.5204 & 0.11308 \\
\hline Intensitas Aset Biologis & 50 & 0.00 & 0.67 & 0.2624 & 0.20768 \\
\hline Kepemilikan Publik & 50 & 0.03 & 0.93 & 0.3343 & 0.19857 \\
\hline Rapat Komite Audit & 50 & 3.00 & 14.00 & 5.6800 & 2.73630 \\
\hline Valid N (listwise) & 50 & & & & \\
\hline
\end{tabular}

Sumber: Data Olahan.

Uji Normalitas

Tabel 3

Uji Normalitas

\begin{tabular}{|l|l|}
\hline $\mathrm{N}$ & 50 \\
\hline Kolmogorov Smirnov Z & 0.917 \\
\hline Asymp. Sig. (2-tailed) & 0.369 \\
\hline
\end{tabular}

Sumber: Data Olahan.

Tabel 3 menunjukkan nilai 0,917 dengan tingkat signifikansi sebesar 0,369. Hasil Kolmogorov-Smirnov menunjukkan signifikansi diatas 0,05 maka menunjukkan data residual terdistribusi secara normal.

\section{Uji Multikolinearitas}

Tabel 4

Hasil Uji Multikolinearitas

\begin{tabular}{lll}
\hline Variabel & Tolerance & VIF \\
\hline Intensitas Aset Biologgis & 0,964 & 1,037 \\
Pertumbuhan Perusahaan & 0,960 & 1,041 \\
Rapat Komite Audit & 0,753 & 1,329 \\
\hline
\end{tabular}

Sumber: Data Olahan.

Tabel 4 di atas terlihat bahwa semua variabel independen memiliki nilai Tolerance $>0,1$ dan nilai VIF < 10 . Jadi dapat disimpulkan bahwa model regresi terbebas dari multikolonieritas antar variabel.

\section{Uji Heteroskedastisitas}

Uji heteroskedastisitas bertujuan untuk melihat apakah dalam model regresi terjadi ketidaksamaan variabel pengganggu dari suatu pengamatan dengan pengamatan yang lain. Untuk mendeteksi ada tidaknya heteroskedastisitas dilakukan dengan melihat ada tidaknya pola tertentu pada grafik scatterplot antara SRESID dan ZPRED dimana sumbu Y adalah Y yang telah diprediksi, dan sumbu X adalah residual (Y prediksi - Y sesungguhnya) (Gozali, 2013). Berikut merupakan gambar dari hasil uji heteroskedastisitas:

\section{Gambar 2}

Uji Heteroskedastisitas

Scatterplot

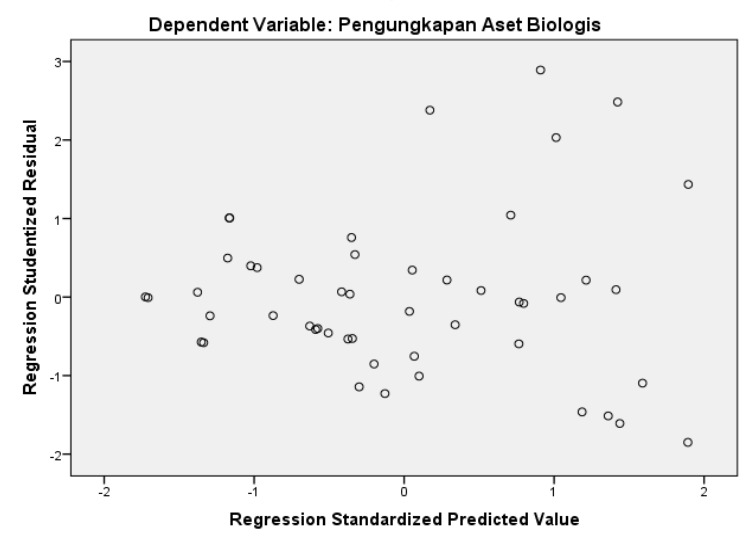


Viona Azzahra et al, Determinan Pengungkapan Aset Biologis (Studi Empiris pada Perusahaan Agriculture yang Terdaftar di Bursa Efek Indonesia

Uji heteroskedastisitas dengan scatterplot menunjukkan titik-titik yang menyebar secara tidak beraturan secara acak di atas maupun dibawa angka 0 pada sumbu Y. Dengan demikian maka dapat ditarik kesimpulan bahwa tidak terjadi heteroskedastisitas pada model regresi, sehingga model regresi layak digunakan.

\section{Uji Autokorelasi}

Uji autokorelasi bertujuan untuk menguji apakah dalam suatu modelregresi linear ada korelasi antara kesalahan pengganggu pada periode $t$ dengankesalahan dengan periode $\mathrm{t}-1$ (sebelumnya) (Gozali, 2013). Pengujian autokorelasi dilakukan dengan menggunakan DW-Test (Durbin Watson Test). Berikut merupakan hasil uji autokorelasi:

Tabel 5.

Hasil Uji Autokolerasi

\begin{tabular}{|l|l|l|l|l|l|}
\hline Model & R & R Square & Adjusted R Square & Std. Error of the Estimate & DW \\
\hline 1 & $0,490^{\mathrm{a}}$ & 0,241 & 0,154 & 0,06753 & 2,154 \\
\hline
\end{tabular}

Sumber: Data Olahan.

\section{Analisis Regresi Berganda}

\section{Koefisien Determinasi $\left(R^{2}\right)$}

Berdasarkan tabel 5 hasil uji adj R Square adalah 0,241 atau 24\% dan Adjusted R Square 0,154 atau 15\%, hasil ini menujukkan bahwa kontribusi variabel independen (intensitas aset biologis, pertumbuhan perusahaan, leverage, kepemilikan publik dan rapat komite audit dapat mejelaskan variabel dependen sebesar $24 \%$, sedangkan sisanya dijelaskan variabel lain diluar penelitian. Nilai Adj $\mathrm{R}^{2}$ penelitian ini terbilang kecil yang disebabkan variasi data penelitian yang berdampak pada besarnya varians error. Namun demikian, nilai adj $R^{2}$ yang kecil ini tidak mempengaruhi signifikansi variabel independen terhadap variabel dependen (pengungkapan aset biologis).

\section{Uji statitik $t$ ( $t$-Test)}

Uji $t$ digunakan untuk mengetahui apakah variabel-variabel independen secara parsial berpengaruh signifikan atau tidak terhadap variabel dependen. Derajat signifikansi yang digunakan adalah 0,05. Apabila nilai signifikan lebih dari derajat kepercayaan (Sig<alpha) maka kita menerima hipotesis alternative, Output uji-t dapat dilihat pada tabel 6 dibawah ini

Tabel 6

Uji Beda (Mann-Whitney)

\begin{tabular}{|l|r|}
\hline & Skor \\
\hline Mann-Whitney U & 43,000 \\
\hline Wilcoxon W & 179,000 \\
\hline Z & $-3,220$ \\
\hline Asymp. Sig. (2-tailed) &, 001 \\
\hline Exact Sig. [2*(1-tailed Sig.)] &, $001^{\text {b }}$ \\
\hline
\end{tabular}

Sumber: Data Olahan.

Berdasarkan ouput "test Statistics" dalam uji mann-whitney di atas diketahui bahwa nilai Asymp. Sig. (2-tailed) sebesar 0,01 lebih kecil dari < nilai probibalitas 0,05. Oleh karena itu kesimpulan bahwa Hipotesis diterima.Dengan demikian dapat dikatakan bahwa ada perbedaan pengungkapan aset biologis sebelum dan setelah disahkan PSAK 69.

Tabel 7

Hasil Uji Beda

\begin{tabular}{|c|c|c|c|c|}
\hline & Tahun & $\mathrm{N}$ & Mean Rank & Sum of Ranks \\
\hline \multirow{3}{*}{ Skor } & 2017 & 17 & 11,19 & 179,00 \\
\hline & 2018 & 17 & 21,81 & 349,00 \\
\hline & Total & 34 & & \\
\hline
\end{tabular}

Sumber: Data Olahan.

Tabel 7 di atas menunjukkan Mean Rank atau rata-rata prngungkapan pada tiap tahun 11,19 lebih rendah dari pada peringkat kedua, yaitu 21,81. Nilai U sebesar 43 dan nilai W sebesar 179.Apabila dikonversikan ke nilai $\mathrm{Z}$ maka besarnya $-3,220$. Nilai Sig 0,001 $<0,05$. Apabila nilai sig $<0,05$ maka hasil uji diatas disimpulkan terdapat perbedaan antara pengungkapan aset biologis tahun 2017 dengan pengungkapan aset biologis tahun 2018.

1) Hipotesis 1 
Berdasarkan tabel hasil uji statistik t menunjukan nilai t-statistik intensitas aset biologis adalah $-2,463$, dengan nilai signifikansi sebesar 0,000 yang lebih kecil dari $\alpha=5 \%(0,000<0,05)$. Karena tingkat signifikansi lebih kecil dari $\alpha$ $=5 \%$, maka intensitas aset biologis berpengaruh terhadap pengungkapan aset biologis pada perusahaan sektor agrikultur yang terdaftar di Bursa Efek Indonesia (BEI) periode 2015-2018, sehingga disimpulkan $\mathrm{H}_{1}$ diterima.

2) Hipotesis Kedua

Berdasarkan tabel hasil uji statistik t menunjukan nilai t-statistik kepemilikan publik adalah 0,382 , dengan nilai signifikansi sebesar 0,014 yang lebih kecil dari $\alpha=5 \%(0,014<0,05)$. Karena tingkat signifikansi lebih kecil dari $\alpha$ $=5 \%$, maka Hasil kepemilikan publik berpengaruh terhadap pengungkapan aset biologis pada perusahaan sektor agrikultur yang terdaftar di Bursa Efek Indonesia (BEI) periode 2015-2018, sehingga $\mathrm{H}_{2}$ diterima.

3) Hipotesis Ketiga

Berdasarkan tabel hasil uji statistik $\mathrm{t}$ menunjukan nilai t-statistik rapat komite audit adalah 0,336 dan bertanda positif, dengan nilai signifikansi sebesar 0,032 yang lebih kecil dari $\alpha=5 \%(0,032<0,05)$. Karena tingkat signifikansi lebih kecil dari $\alpha=5 \%$, maka rapat komite audit berpengaruhterhadap pengungkapan aset biologis pada perusahaan sektor agrikultur yang terdaftar di Bursa Efek Indonesia (BEI) periode 2015-2018.

Berdasarkan tabel hasil uji statistik t menunjukan nilai t-statistik kepemilikan publik adalah 0,382 dan bertanda positif, dengan nilai signifikansi sebesar 0,014 yang lebih kecil dari $\alpha=5 \%(0,014<0,05)$. Karena tingkat signifikansi lebih kecil dari $\alpha=5 \%$, maka hipotesis $\left(\mathrm{H}_{1}\right)$ diterima. Hasil ini membuktikan bahwa kepemilikan publik berpengaruh positif terhadap pengungkapan aset biologis pada perusahaan sektor agrikultur yang terdaftar di Bursa Efek Indonesia (BEI) periode 2015-2018.

Berdasarkan hasil uji statistik t menunjukkan nilai t-statistik intensitas aset biologis membuktikan bahwa intensitas aset biologis berpengaruh positif terhadap pengungkapan aset biologis. Pengaruh positif antara intensitas aset biologis terhadap pengungkapan aset biologis disebabkan aset biologis merupakan aset utama yang dikelola perusahaan agrikultur. Sebagai aset utama intensitas aset biologis akan mempengaruhi pengungkapan didalam laporan tahunan perusahaan. Hal ini juga berdampak bagi perusahaan karena investor dan pemakai laporan keuangan lainnya dapat mengetahui apa saja aset biologis yang dikelola oleh perusahaan dan mengetahui bagaimana pengakuan, pengukuran dan seberapa besar kontribusi aset biologis terhadap total aset perusahaan. Teori agency menjelaskan bahwa Agent dalam menjalankan perusahaan mempuyai informasi yang lebih banyak dibandingkan dengan principal. Kondisi ini mengakibakan terjadinya ketidakseimbangan informasi atau asimetri informasi. Healy \& Palepu (2001) menjelaskan bahwa salah satu cara untuk mengatasi permasalahan tersebut adalah adanya pengungkapan informasi oleh agent sehingga principal mampu melakukan evaluasi tentang apakah investasi mereka telah dikelola dengan baik atau tidak oleh agent. Pengungkapan merupakan salah satu mekanisme yang tepat untuk memonitoring kinerja agent serta dapat meningkatkan kredibilitas perusahaan di mata pamegangsaham. Artinya semakin tinggi intensitas aset biologis tidak menjamin perusahaan melakukan pengungkapan aset biologis pada perusahaannya. Hasil penelitian ini didukung oleh penelitian sebelumnya yaitu penelitian Rute Dan Patricia (2014), Marselina et al (2018), Selahudin et al (2018), Yurniwati et al (2018) dimana intensitas aset biologis berpengaruh terhadap pengungkapan aset biologis yang lebih tinggi memiliki lebih informasi

Berdasarkan hipotesis keempat pada penelitian ini menemukan bahwa kepemilikan publik berpengaruh positif terhadap pengungkapan aset biologis. Semakin besar kepemilikan publik maka semakin besar juga pengungkapan aset biologis yang ada pada perusahaan, dan berdasarkan hasil penelitian menemukan bahwa rapat komite audit berpengaruh positif signifikan terhadap pengungkapan aset biologis . Jumlah rapat komite audit dilaksanakan untuk mengevaluasi kualitas laporan keuangan. Dan semakin rutinnya komite audit melakukan rapat maka semakin luas perusahaan melakukan pengungkapan aset biologisnya.

\section{SIMPULAN}

Berdasarkan analisis data dari hasil penelitian ini maka diperoleh kesimpulan sebagai berikut hasil penelitan ini membuktikan bahwa intensitas aset biologis, kepemilikan public, dan rapat komite audit memiliki pengaruh terhadap pengungkapan aset biologis pada perusahaan agrikultur yang terdaftar di BEI selama tahun 2015-2018. Hasil uji beda dengan mann whitney menemukan bahwa adanya perbedaan pengungkapan sebelum dan setelah disahkannya PSAK 69.

\section{DAFTAR PUSTAKA}

Argilés, J. M., Garcia-Blandon, J., \& Monllau, T. (2011). Fair value versus historical cost-based valuation for biological assets: Predictability of financial information. Revista de Contabilidad, 14(2), 87-113.

Allegrini, M., \& Greco, G. (2013). Corporate boards, audit committees and voluntary disclosure: Evidence from Italian Listed Companies. Journal of Management and Governance, 17(1), 187-216. 
Viona Azzahra et al, Determinan Pengungkapan Aset Biologis (Studi Empiris pada Perusahaan Agriculture yang Terdaftar di Bursa Efek Indonesia

Baroroh, N., Yanto, H., Fajarrini, I., \& Agustina, L. (2018). Accounting of Biological Assets in Indonesian Plantation Companies. KnE Social Sciences, 3(10), 46.

Daniel, S. Jung, B., Pourjalali, H. and Wen, E. (2010).Firm characteristics influencing responses towards adoption of the fair value accounting option: A survey of chief financial officers of U.S.

Elad, C. (2004). Fair value accounting in the agricultural sector: some implications for international accounting harmonization. European Accounting Review, 13(4), 621-641.

Ettredge, M., Johnstone, K., Stone, M., \& Wang, Q. (2011). The effects of firm size, corporate governance quality, and bad news on disclosure compliance. Review of Accounting Studies, 16(4), 866-889.

Gallery, G., Cooper, E., \& Sweeting, J. (2008). Corporate disclosure quality: Lessons from Australian companies on the impact of adopting international financial reporting standards. Australian Accounting Review, 18(3), 257-273.

Ghozali, I. 2013. "Aplikasi Analisis Multivariate Dengan Program". Edisi Ketujuh. Semarang: Badan Penerbit Universitas Diponegoro, Vol., No., hlm.

Glaum, M., Schmidt, P., Street, D. L., \& Vogel, S. (2013). Compliance with IFRS 3-and IAS 36-required disclosures across 17 European countries: Company-and country-level determinants. Accounting and Business Research, 43(3), 163-204.

Gonçalves, R., \& Lopes, P. (2014). Firm-specific Determinants of Agricultural Financial Reporting. Procedia - Social and Behavioral Sciences, 110, 470-481.

Hayati, Mimi. Elviana. Martina. 2017. Peranan Sektor Pertanian Dalam Pembangunan Wilayah Kabupaten Bireuen Provinsi Aceh. Jurnal S. Pertanian 1 (3) : 213 - 222.

Healy, P. M., \& Palepu, K. G. (2001).Information asymmetry, corporatedisclosure, and the capital markets:A review of the empiricaldisclosure literature. Journal of Accounting and Economics 31, 405-440.

Herbornh, Kathleen dan Herbornh J. 2006.Internasional Accounting Standard (IAS 41): Whar are The Implication for Reforting Forestassets?. Manajemenn And Policy. 5(2):175-189.

Hope, O. K., \& Thomas, W. B. (2008). Managerial empire building and firm disclosure. Journal of Accounting Research, 46(3), 591-626.

Ikatan Akuntansi Indonesia (IAI). 2018. Pernyataan Standar Akuntansi Keuangan (PSAK) No.69: Agrikultur, Jakarta: IAI

IAS (International Accounting Standard) 41-Agrikultur

Jensen, M. C., \& Meckling, W. H. (1976).Theory of the Firm : Managerial Behavior, Agency Costs and Ownership Structure, 3, 305-360

Kakalta, M. (2014). Evaluation of biological assets and agricultural Disclosures required by companies in Philippines. l(1), 83-89.

Krisna, Made Satriajaya. 2013. Tingkat Likuiditas, Leverage, Ukuran Perusahaan, Reputasi Kantor Akuntan Publik dan Pengungkapan Sukarela Pada Manufaktur Di Bursa Efek Indonesia.E-Jurnal Akuntansi Universitas Udayana. 162-178.

Korompis, C. W. M. (2016). Analisis Perlakuan Akuntansi Agrikultur Pada Petani Kelapa Pada Desa Di Daerah Likupang Selatan: Dampak Rencana Penerapan Ed Psak No.69 Tentang Agrikultur. Going Concern : Jurnal Riset Akuntansi, 11(2), 23-33.

Laksmana, I. (2008). Corporate board governance and voluntary disclosure of executive compensation practices. Contemporary Accounting Research, 25(4).

Li, J., Pike, R., \& Haniffa, R. (2008). Intellectual capital disclosure and corporate governance structure in UK firms. Accounting and Business Research, 38(2), 136-159.

Marselina, Sylvia, \& Hastutie. (2018). Pengaruh Biological Asset Intensity, Ukuran Perusahaan, Konsentrasi Kepemilikan, Jenis KAP, dan Profitabilitas Terhadap Biological Asset Disclosure. Jurnal Akuntansi \& Keuangan Daerah, 13(2), 56-75.

Munsaidah, S., Andini, R., \& Supriyanto, R. (2016). Analisis Pengaruh Firm Size, Age, Profitabilitas, Leverage, dan Growth Perusahaan terhadap Corporate Social Responsibility (Csr) pada Perusahaan Property Dan. Jurnal.Unpand.Ac.Id, 2(2).

Muslich, Mohammad. 2003. Manajemen Keuangan Modern. Jakarta. Bumi Aksara

Nugraheni, B. D. (2012). Faktor-Faktor Yang Berpengaruh Terhadap Luas Pengungkapan Sukarela Dalam Laporan Tahunan. EKUITAS (Jurnal Ekonomi Dan Keuangan), 16(3), 352.

Nur, M., \& Priantinah, D. (2012). Analisis Faktor-Faktor Yang Mempengaruhi Pengungkapancorporate Social Responsibility Di Indonesia (Studi Empiris Pada Perusahaan Berkategori High Profile Yang Listing Di Bursa Efek Indonesia). Nominal, Barometer Riset Akuntansi Dan Manajemen, 1(2).

Oliveira, L., Rodrigues, L. and Craig, R. (2006). Firm-specific determinants of Intangibles reporting; Evidence from the Portuguese stock market.Journal of Human Resource Costing and Accounting, 10(1), 11-33. 
Viona Azzahra et al, Determinan Pengungkapan Aset Biologis (Studi Empiris pada Perusahaan Agriculture yang Terdaftar di Bursa Efek Indonesia

O'Sullivan, M., Percy, M., \& Stewart, J. (2008). Australian evidence on corporate governance attributes and their association with forward-looking information in the annual report. Journal of Management and Governance, 12(1), 5-35.

Owusu-Ansah, S. (1998).The Impact of Corporate Attributes on the Extent of Mandatory Disclosure and Reporting by Listed Companies in Zimbabwe, 33(5), 605-631.

Olímpia, M., Sousa, A. De, \& Pascoal, F. (2013). A contabilização dos ativos biológicos : problemática reconhecimento da mensuração e.

Pratama, A., \& Yulianto, A. (2015). Faktor Keuangan Dan Corporate Governance Sebagai Penentu Pengungkapan Sustainability Report. Accounting Analysis Journal, 4(2), 1-10.

Pricewater House Coopers. (2009). A practical guide to accounting for agricultural assets. Price Water House Coopers, (November), 24. Retrieved from www.pwc.com/ifrs

Sa'diah, Lentina Diah, Muhaimin Dimyanti \& Wahyuning Mumiati. 2019. Pengaruh Biological Asset Intensity, Ukuran Perusahaan dan Tingkat Internasional terhadap pengungkapan Aset Biologis. pada Perusahaan Agriculture yang terdaftar di BEI 2013-2017).Progress Conference. E-ISSN. (2) 2622-304

Scott, W.R. 2012. Financial Accounting Standar Theory Fifth Edition. Teronto: Prentice Hall

Selahudin, N. F., \& Sfarhanaunitenedumy, E. (2018). Biological Assets: The Determinants of Disclosure. Global Business and Management Research, 10(3), 170-179.

Sugiyono. 2015. Metode Penelitian Manajemen. Bandung: Alfabeta.

Suhardjanto, D., Dewi, A., Rahmawati, E., \& Firazonia, M. (2012). Peran Corporate Governance Dalam Praktik Risk Disclosure Pada Perbankan Indonesia. Jurnal Akuntansi \& Auditing, 9(1), 16-30.

Silva, R., Nardi, P., \& Ribeiro, M. (2015). Earnings Management and Valuation of Biological Assets. Brazilian Business Review, 12(4), 1-26.

Siregar, R. M. M., \& Priantinah, D. (2017). Pengaruh Good Corporate Governance dan Kepemilikan Saham Publik Terhadap Tingkat Pengungkapan Corporate Social Responsibility Good Corporate Governance and Public Ownership Effect on CSR Disclosure. Jurnal Profita, (40), 1-18.

Sudana, I Made. 2011. Manajemen keuangan perusahaan :Teori \& Praktik. Jakarta : Erlangga

Syafa'at, Nizwar dan Pantjar Simatupang, 2016.Kebijakan Pemantapan Ketahanan Pangan Nasional Ke Depan. Edisi, N. 47/XV.

Syamsuddin, Lukman. 2009. Manajemen Keuangan Perusahaan : konsep aplikasi dalam : Perencanaan, Pengawasan dan Pengambilan Keputusan. Jakarta: Rajawali Pers

Todaro, Michael dan Smith, 2011, Pembangunan Ekonomi, Jilid 1 Edisi kesembilan, Erlangga, Jakarta.

Weston, J. Fred dan Copeland, Thomas E. 1999. Manajemen Keuangan, Edisi Kesembilan,Jilid 2. Jakarta: Binarupa Aksara.

Wolk, H. I., M. G. Tearney, dan J. L. Dodd. 2001. A Conceptual and Instutional Aproach Accounting Theory. 5th edition.South-Western College Publishing.USA

Yurniwati, Y., Djunid, A., \& Amelia, F. (2018). Effect of Biological Asset Intensity, Company Size, Ownership Concentration, and Type Firm against Biological Assets. The Indonesian Journal of Accounting Research, 21(1), 121-146. 